\title{
Work-Family Conflict and Health: A Study of Workplace, Psychological, and Behavioral Correlates
}

\author{
Susan R. Madsen \\ Cameron R. John \\ Duane Miller \\ Utah Valley State College
}

\begin{abstract}
Quantitative methods are used to shed light on the relationships among work-family conflict, health, and other workplace, psychological, and behavioral constructs, i.e., organizational commitment, management/leadership relations, job knowledge and skills, job demands, workplace social relations, and readiness for change. A survey questionnaire was used to collect data regarding the perceptions of 464 employees in four organizations. Negative correlations were found between work-family conflict and all variables except job knowledge and skills. Significant relationships were also discovered between health and all study variables. Multiple regressions were used to explore the relationships between the demographic variables and work-family conflict and health.
\end{abstract}

\section{Introduction}

Improving the performance of employees has been a topic of great interest to practitioners as well as researchers. Work performance is the focus of much of the literature, e.g., Tracey, Hinkin, Tannenhaum, and Mathieu (2001). Throughout the past few decades however, performance research has also centered on a variety of nonwork issues including work-family conflict (Carlson \& Perrewe, 1999) and mental and physical health (Ho, 1997; Voit, 2001). The term "work-family conflict" includes the tensions, challenges, and struggles individuals may perceive or feel related to their expectations, duties or requirements, and behaviors in, for, and between each role (work and family). For example, Thompson, Beauvais, and Lyness (1999) discovered that organizations that did not foster a more balanced work-family life for employees contributed to stress and tensions in employees' personal lives, which affected their ability to concentrate and be productive and creative on the job. Netemeyer, Boles, and McMurrian (1996) found that work-family conflict was negatively related to job performance. Other researchers (Burley, 1989; Eagle, Miles \& Icenogle, 1997; Tompson \& Werner, 1997) concluded that greater work-family conflict was linked to reduced concentration and attention on the job and was also linked to absenteeism, tardiness, turnover, low job commitment, low job involvement, overall performance, and reduced organizational citizenship, which, in turn, reduced overall work performance. The literature also supports important connections between mental and physical health and workplace performance. Voit (2001) found that workplace fitness and health programs improved employees' physical and mental health, and this improvement appeared to translate into positive effects on job performance and productivity. Ho (1997) reported that increased employee wellness (physical and mental) through participation in workplace health programs, led to 
improved job performance through reduced employee stress and absenteeism and increased job satisfaction.

Research continues to be conducted in both the work-family conflict and health arenas as complex workplace relationships (e.g., mediators, antecedents, determinants, outcomes, and correlates) have been explored. As these relationships are investigated, a deeper understanding of these phenomena can lead to the design and development of support systems and programs that result in individual and organizational performance improvements. But first, it is important to study the basic correlations among work-family conflict, health, and other potentially related constructs such as organizational commitment, management/leadership relations, job knowledge and skills, job demands, social relationships in the workplace, and readiness for change. As new or existing relationships are discovered and/or supported, future research can then determine the specific variable relationship directions, e.g., antecedent, mediator, or outcome. Hence, the purpose of this study is to shed light on the basic connections between work-family conflict, health, and other workplace, psychological, and behavioral constructs. The literature has shown performance improvements through reduced work-family conflict and improved health. By investigating connections between these and other selected constructs, an enhanced understanding of possible influential factors, ultimately leading to workplace performance, can be acquired.

\section{Theoretical Frameworks}

Although role conflict theory has already received a great deal of attention in the literature throughout the past few decades, it provides one of two comprehensive theoretical frameworks for this study. This theory states that experiencing ambiguity or conflict within a role will result in an undesirable state. Because of conflicting demands (e.g., time, incompatible behaviors) among roles, multiple roles lead to personal conflict as it becomes more difficult to perform each role successfully (Grandey \& Cropanzano, 1999). Biernat explained that role conflict exists when role expectations are incompatible. "Role strain or difficulty in meeting role demands is inevitable" and a person "must continually make role decisions and bargains in order to meet role requirements" (1997: 9). Greenhaus and Beutell suggested that work-family conflict exists when

1) time devoted to the requirements of one role makes it difficult to fulfill requirements of another;

2) strain from participation in one role makes it difficult to fulfill requirements of another; and

3 ) specific behaviors required by one role make it difficult to fulfill the requirements of another. (1985: 76)

In addition, Gutek, Searle, and Klepa (1991) explained that there are two directions of possible influence or spill over, i.e., work-to-family conflict and family-to-work conflict. Work-to-family conflict stems from interference of events in the work role with an individual's ability to perform effectively in his or her family role. Family-to-work conflict stems from interference of events or responsibilities in the family role with an 
employee's ability to perform his or her job effectively. Aryee, Luk, Leung, and Lo (1999) purported that to truly understand work-family conflict both directions must be considered.

A second theory that appears to umbrella the role conflict theory as well as general health principles and findings is the spillover theory. Although it has primarily been used to explain how work influences family life and how family influences work life, it can also be used in thinking about how an individual's health status may affect other variables. In the work-family area, positive spillover would be affirmed when the satisfaction, energy, happiness, and stimulation an individual has at work would cross over into positive feelings and energy at home or when positive satisfaction, energy, and happiness from home crosses over to a positive experience at work (Higgins, Duxbury, Lee, \& Mills, 1992). This could also be broadened to encompass the positive influence that low levels of work-family conflict or good mental and physical health have on job performance and other workplace outcomes. Again, in the work-family conflict arena, negative spillover from work to family is demonstrated when the problems, conflicts, or energy at work has strained and preoccupied an individual, making it difficult to participate in family life effectively and positively (Foley \& Powell, 1997). Of course, negative spillover from family to work (e.g., divorcing, problems with children, or the death of a close friend or family member) can also be destructive. The spillover theory can also be broadened to encompass the negative effects high levels of work-family conflict or poor mental and physical health can have on various positive workplace outcomes.

\section{Work-Family Conflict Literature}

Reported are important relationships between work-family conflict and various constructs. First, many studies have found relationships between work-family conflict and health (mental and physical). Most of the findings support the premise that increased work-family conflict can lead to increased health concerns and problems. For example, Kinnunen and Mauno (1998) and Netemeyer et al. (1996) found a relationship between increased work-family conflict and increased physical symptoms or somatic complaints. Grandey and Cropanzano (1999) and others have discovered relationships between work-family conflict and overall physical health. Many researchers (e.g., Netemeyer et al., 1996; Thomas \& Ganster, 1995) have concluded that increased workfamily conflict is related to increased depression and other psychological issues (e.g., strain anxiety, irritability, and hostility). Overall, Frone, Russell, and Cooper stated, "Cross-sectional research provides consistent evidence that work-family conflict is positively associated with a host of adverse health-related outcomes" (1997: 325).

Second, Good, Page, and Young (1996) found an indirect relationship (through job satisfaction) between work-family conflict and organizational commitment. In other words, higher conflict was associated with lower commitment. Tompson and Werner's study suggested that "when individuals experience high levels of work/nonwork conflict, this impacts negatively on their commitment to their organization, which in turn leads to lower organizational loyalty" (1997: 594). Carlson, Kacmar, and Williams (2000) found that work-family conflict, particularly work-to-family conflict, did not have an impact on organizational commitment; however, organizational commitment was negatively 
correlated with family-to-work conflict specifically related to behavior, i.e., challenges when an employee's behavior or expected behavior at work and home are different. Kirchmeyer (1995) discovered that negative nonwork-to-work spillover was slightly related to organizational commitment, being female, age, and having children under 12. Kossek and Ozeki explained, "The results of research on the relationship between workfamily conflict and organization commitment are inconsistent" (1999: 22).

Third, Carlson et al. (2000) also discovered that work involvement does significantly correlate with work-to-family conflict. After conducting a review of the research, they also stated, "Although there are exceptions, most research shows that people who are very involved in their work tend to have higher levels of work-family conflict of all types" (2000: 23). This may provide support for a relationship between job demands and workfamily conflict. In addition, Aryee, Luk, Leung, and Lo (1999) found that work overload (high job demand) is strongly related to both work-to-family and family-to-work conflict. Little is known from research about the relationship between job knowledge and skills and work-family conflict, but role ambiguity has been researched. It is clear that employees who have stress related to uncertainty or ambiguity in their jobs (often related to a lack of knowledge and skills) have higher perceptions of work-family conflict (Fu \& Shaffer, 2001).

Fourth, Carlson et al. (2000) found that work social support (which may have some similarity to social relations in the workplace and management/leadership relations) is related to work-family conflict, primarily the conflict stemming from work and interfering with family (work-to-family conflict). Carlson and Perrewe studied the role of social support in the stressor-strain relationship and concluded that "social support may reduce perceived role stressors (conflict and ambiguity) and time demands, and thus, indirectly decreases work-family conflict" (1999: 521). Although social support and relationships between co-workers and with management are not exactly the same, there are some similarities that may provide some support for a directional hypothesis. Thomas and Ganster (1995) found that supervisor support reduced work-family conflict, while Batt and Valcour (2003) discovered no relationship. Anderson, Coffey, and Byerly (2002) found that managerial support was negatively and significantly correlated with work-to-family conflict and family-to-work conflict, while Frone, Yardley, and Markel (1997) concluded that supervisor support was related to work-to-family conflict and not family-to-work conflict, and co-worker support was related to neither. On the other hand, Fu and Shaffer (2001) found that work-to-family and family-to-work conflict was related to both supervisor social support and coworker social support. Therefore, the findings appear to be mixed.

Finally, little research has been reported on possible relationships between work-family conflict and readiness for change. However, as already discussed, high levels of workfamily conflict have been linked to negative physiological and psychological health problems. And, one study (Cunningham et al., 2002) has reported relationships between change readiness and emotional health and availability. Further, Madsen (2003a) purported an indirect connection between wellness and readiness for change. Based on the above arguments, we propose the following: 
Hypotheses 1a-f: Work-to-family and family-to-work conflict will be negatively related to perceived mental and physical health (a), organizational commitment (including loyalty, involvement, and identification) (b), job knowledge and skills (c), social relations (d), management/leadership support (e), and readiness for organizational change (f).

Hypotheses 2a-b: Job demands will be positively related to (a) work-to-family and (b) family-to-work conflict.

\section{Physical and Mental Health Literature}

Much of the current management literature on mental and physical health and wellness is related to the effects of implementing corporate health and wellness initiatives and programs on employees and employers. Although this study focuses on an employee's perceptions of health (unrelated to whether his or her company had a health or wellness program), a review of this literature can be helpful in creating directional hypotheses. Overall, Lansing and Kleiner stated, "The benefits received from developing a health and fitness attitude within a company's culture include an improved ability to handle stress, increased energy and stamina, and higher employee morale and team spirit" (1990: i). Further, after reviewing the literature, Rosen (1986) compiled a list of the ways poor health and stress can negatively impact a company's bottom line. These include job dissatisfaction, decreased motivation, poor morale, lack of commitment to quality, increased errors and missed deadlines, poor decision making, group conflict, complaints, accidents, EEO complaints, fatigue, premature retirement, poor interpersonal communication, absenteeism, turnover, reduced productivity, excessive health-care costs, short and long-term disability, workers' compensation premiums, accidents, and early pension payments.

The research also touches, more specifically, on some constructs related to this study. Researchers have confirmed a relationship between "implementing an employee fitness and health program into the workplace" and its impact on the "overall physical and mental health of the employees" (Voit, 2001: 274). In fact, Ho (1997) found that employees from organizations that offered wellness programs reported more commitment to their organizations, higher perceptions of satisfaction with co-worker relations, lower experienced work stress, higher work condition satisfaction, higher satisfaction with accomplishments, and lower absenteeism. Of course this may tell more about the nature of the organizations that have these programs than about the results of the programs. Further, Daley and Parfitt (1996) found that employees participating in health promotion interventions at work improved in their attitudes related to organizational commitment, supervision (management/leadership relations), and working conditions. And, Thomas and Ganster (1995) agreed and stated that managerial interventions had a positive impact on the general well-being of employees. Finally, Anderson, Coffey, and Byerly (2002) found that the perception of low managerial support indirectly relates, through work-family conflict, to increased stress which has been shown to effect personal health.

The literature on the relationships among health and social relations, job demands, and readiness for change was also explored. First, Daley and Parfitt (1996) did not find a 
significant relationship between health and relationships with co-workers. Yet, Greenberg et al. (1995) did find that unhealthy workers diminished performance can dramatically affect coworker relations and performance through increased accidents and errors. Second, Yetman (1998) reported that employees who participated in a controlled exercise program were better able to handle job demands through improved stamina, energy, and patience, as well as enhanced concentration and decision-making powers. Further, Grandey and Cropanzano (1999) found a relationship between poor physical health and work role stress. Finally, Madsen (2003a) proposed an indirect relationship between employee wellness and readiness for change but research is limited. Based on the above arguments, we propose the following:

Hypotheses 3a-e: Mental and physical health will be positively related to perceived organizational commitment (including loyalty, involvement, and identification) (a), job knowledge and skills (b), social relations (c), management/leadership support (d), and readiness for organizational change $(e)$.

Hypothesis 4: Mental and physical health will be negatively related to job demands.

In addition to the four proposed hypotheses, we were also interested in exploring the various relationships between various demographics (gender, employee age, marital status, educational level, length of time with employer, and number of children) and each of the study variables (work-family conflict, health, organizational commitment, management/leadership relationships, job knowledge and skills, job demands, social relations and readiness for change).

\section{Research Methods}

\section{Sample}

The sample for this research study included respondents from four business organizations (three for-profit and one non-profit) within the state of Utah with approximately 200 to over 2,000 local employees. These organizations varied greatly in industries, products, and services. One organization distributed surveys to all employees while another distributed surveys to all employees within six predetermined departments. A third conducted a random sample of all supervisors, management, and leadership within the organization. Finally, we selected a random sample of about twothirds of all employees for the fourth company. In addition to the actual survey, a letter of consent which had been approved through our Institutional Review Board was also given to each employee.

A key contact at each organization was used to distribute surveys. This individual had a list of the employees to be given surveys and the survey number employees should be given. We kept a list of numbers given to each organization, and we tracked returned surveys. Researchers did not have a list of employee names, and contacts did not see completed surveys so confidentiality was maintained. Survey numbers were used to identify organizations. After approximately ten days we asked the organizational contacts to provide a general reminder to all participants to return surveys. Additional 
copies of surveys were given to the contacts so that they could provide them to employees who may have misplaced their original copies. For three organizations, preaddressed and stamped envelopes were provided so employees could mail surveys directly to us. One organization asked participants to seal completed surveys in envelopes provided and then to put them in large envelopes located in each department (this was the method used for all employee surveys for this organization). The following week a researcher picked up the sealed envelopes. Again, before the surveys were distributed, we asked the contacts at each organization to encourage their employees to return as many surveys as possible so that results would be more accurate.

\section{$\underline{\text { Measures }}$}

For this study, work-to-family conflict, family-to-work conflict, mental health, and physical health served as the four dependent variables. Organizational commitment (including loyalty, involvement, and identification), management/leadership relationships, job knowledge and skills, job demands, social relations in the workplace, and readiness for change served as independent variables. Intervening demographic variables included gender, age, marital status, educational level, number of children, and length of time with company. We adapted existing scales for this research project, and we included six demographic items. All scales, except for the readiness for change scale, used a 7-point (strongly disagree to strongly agree) scale (see Exhibit for actual questionnaire).

\section{Work-family Conflict}

Six slightly adjusted items from an 18-item multidimensional measure of work-family conflict constructed and validated by Carlson et al. (2000) were used to measure workto-family conflict (3-items) and family-to-work conflict (3 items). These adjusted items were used in a later study (Madsen, 2003b), and the reliability was consistent with Carlson et al.'s (2000) original items and study. The original instrument used a 5-point Likert-type scale ranging from 1 (strongly disagree) to 5 (strongly agree), but we changed it to a 7-point scale for consistency with other scales. According to Carlson et al. (2000), the instrument was subjected to rigorous development and validation procedures and reliability was established with coefficient alpha with scale reliabilities ranging from .78 to .87 . Reliability for the 6 -item scale dropped substantially from the 18-item instrument: overall work-family conflict measure (alpha=.64); work-to-family conflict (alpha=.58), and family-to-work conflict (alpha=.41).

\section{Organizational Commitment}

A 9-item scale (alpha=.81) was used to measure organizational commitment. This scale, obtained from Mathews and Shepherd (2002), was said to be slightly adapted from Cook and Wall's (1980) British Organizational Commitment Scale. It included three 3 -item subscales: identification (alpha=.68), involvement (alpha=.59), and loyalty (alpha=.66). 


\section{Readiness for Change}

We used Hanpachern's (1997) original 14-item readiness for change scale (with slight alterations) which was based in part on McNabb and Sepic (1995) and several unpublished studies. The stem question asked was "My willingness or openness to...", and one of the items was "work more because of the change is..." Participants were asked to circle one of seven numbers on a Likert scale (1=very unlikely; 7=very likely). Hanpachern (1997) pilot tested three versions of this scale, and the Cronbach's alpha of the final 14-item scale was measured to be .82 which indicates good internal consistency (Hanpachern, Morgan, \& Griego, 1998). Our slightly adjusted instrument also had a Cronbach's alpha of .82.

Health, Management/leadership Relations, Job Knowledge and Skills, Job Demands, and Social Relations

The four final scales were adapted from subscales within Hanpachern's (1997) Revised Margin in Life instrument which had already been modified from the original published survey by Stevenson in 1982. These adapted scales, along with the previous scales discussed, were pilot tested $(n=44)$ to ensure internal consistency. First, the mental and physical 7-item scale was adapted from the subscale mentioned, but a few additional items were added based on a general review of the health component literature. The revised scale included four items focused on mental health (alpha $=.78$ ) and three on physical health (alpha $=.72$ ). Second, a 4-item scale was used to measure an employee's relationship with his or her manager. Our slightly revised scale demonstrated internal consistency at .87. Third, a 3-item scale was used to measure job knowledge and skills. Our revised scale demonstrated internal consistency at .62. Next, a 5-item scale was used to measure job demands and, as with the last three scales mentioned, was adapted from a social relationships subscale of Hanpachern's (1997) Revised Margin in Life scale. This revised scale demonstrated internal consistency at .66. Finally, a 4-item scale (alpha=.70) was used to the social relationships in the workplace.

\section{Demographics}

The participants were asked to check the appropriate box in the demographic section of this questionnaire. Demographics included gender, age range, present marital status, highest educational level, number of children living at home, and length of time with company (see Appendix A for copy of instrument).

\section{Data Analysis Procedure}

A number of statistical tests were used to analyze the results of this study. First, frequencies, means, and standard deviations were used to describe the sample (demographics) and general results. Pearson correlations were used to test magnitude and direction of the relationship for the hypotheses. The primary method of analysis for demographics was a linear multiple regression. This was useful in determining the relationships between the primary constructs (work-to-family conflict, family-to-work 
conflict, mental health, and physical health) and the combination of applicable demographic (predictor) variables for the sample.

\section{Table 1}

Demographic Frequencies

\begin{tabular}{|c|c|c|}
\hline Demographic & Category & Frequencies \\
\hline Sample & Total number & 464 \\
\hline Gender & $\begin{array}{l}\text { Male } \\
\text { Female }\end{array}$ & $\begin{array}{l}222 \\
229\end{array}$ \\
\hline Age range & $\begin{array}{l}\text { Less than } 21 \\
21-30 \\
31-40 \\
41-54 \\
55+\end{array}$ & $\begin{array}{l}10 \\
230 \\
97 \\
92 \\
22\end{array}$ \\
\hline Marital status & $\begin{array}{l}\text { Single } \\
\text { Separated/Divorced } \\
\text { Widowed } \\
\text { Married }\end{array}$ & $\begin{array}{l}96 \\
33 \\
3 \\
316\end{array}$ \\
\hline $\begin{array}{l}\text { Highest educational } \\
\text { level }\end{array}$ & $\begin{array}{l}\text { High School } \\
\text { Associate Degree } \\
\text { Bachelor Degree } \\
\text { Masters Degree } \\
\text { Doctorate Degree }\end{array}$ & $\begin{array}{l}135 \\
141 \\
152 \\
21 \\
2\end{array}$ \\
\hline Age of children & $\begin{array}{l}\text { None } \\
0-5 \\
6-11 \\
12-18 \\
\text { Over } 19\end{array}$ & $\begin{array}{l}180 \\
144 \\
98 \\
87 \\
51\end{array}$ \\
\hline $\begin{array}{l}\text { Length of time with } \\
\text { company }\end{array}$ & $\begin{array}{l}0-6 \text { months } \\
7-11 \text { months } \\
1-2 \text { years } \\
3-5 \text { years } \\
6 \text { or more years }\end{array}$ & $\begin{array}{l}53 \\
63 \\
95 \\
145 \\
95\end{array}$ \\
\hline Company & $\begin{array}{l}A \\
B \\
C \\
D\end{array}$ & $\begin{array}{l}128 \\
145 \\
127 \\
54\end{array}$ \\
\hline
\end{tabular}

*The demographics on approximately 10 surveys were not completed so totals in each demographic group do not equal 464. 


\section{Results}

Of the 758 distributed questionnaires, 469 were returned; and 464 were deemed usable and were included in the study results for a return rate of over 61 percent. Five surveys were returned too incomplete to use. Return rates in the four organizations ranged from 51 percent to 72 percent, and 10 surveys were completed; returned but the survey numbers (used to identify companies and departments) had been removed. Selected demographic results were gather and compiled (see Table 1).

\section{Work-Family Conflict Correlates}

Overall, employees in this study perceived themselves as having moderate to low levels of work-to-family conflict with a statistical mean $(M)$ of 3.32 on the 7-point scale described, and fairly low family-to-work conflict $(M=2.29)$. In addition, employees appeared to be fairly committed to their organizations $(M=5.17)$, and they generally reported their jobs were demanding $(M=5.36)$. These employees reported confidence with their job knowledge and skills $(M=5.84)$, believed they have good management/leadership relationships $(M=5.80)$, were fairly ready for change $(M=$ $5.27)$, and were neutral with regard to their workplace social relationships $(M=3.68)$ (see Table 2).

Table 2

Intercorrelations Among Study Variables

\begin{tabular}{|l|l|l|l|l|l|l|l|l|l|l|l|l|l|l|}
\hline Variable & $M$ & $S D$ & 1 & 2 & 3 & 4 & 5 & $5 a$ & $5 b$ & $5 c$ & 6 & 7 & 8 & 9 \\
\hline 1. WFC & 3.32 & 1.21 & -- & & & & & & & & & & & \\
\hline 2. FWC & 2.69 & 1.03 & .42 & -- & & & & & & & & & & \\
\hline 3. MH & 5.93 & .80 & -.19 & -.25 & -- & & & & & & & & & \\
\hline 4. PH & 5.70 & 1.16 & -.17 & -.17 & .50 & -- & & & & & & & & \\
\hline 5. OC & 5.17 & 1.00 & -.30 & -.25 & .23 & .21 & -- & & & & & & & \\
\hline a. Loy & 4.42 & 1.44 & -.27 & -.17 & .11 & .08 & .87 & -- & & & & & & \\
\hline b. Inv & 5.83 & .88 & -.17 & -.31 & .30 & .24 & .72 & .43 & -- & & & & & \\
\hline c. Iden & 5.25 & 1.27 & -.28 & -.19 & .21 & .23 & .88 & .63 & .53 & -- & & & & \\
\hline 6. JD & 5.36 & 1.28 & .48 & .17 & -.10 & -.16 & -.20 & -.21 & -.08 & -.17 & -- & & & \\
\hline 7. JKS & 5.84 & .77 & -.01 & -.08 & .37 & .17 & .10 & .01 & .24 & .05 & .02 & -- & & \\
\hline 8. SR & 3.68 & 1.06 & -.22 & -.23 & .29 & .21 & .38 & .29 & .31 & .34 & -.17 & .19 & -- & \\
\hline 9. MLR & 5.80 & .84 & -.28 & -.18 & .23 & .17 & .59 & .50 & .35 & .58 & -.22 & .08 & .38 & -- \\
\hline 10. RFC & 5.27 & .73 & -.19 & -.10 & .23 & .18 & .45 & .28 & .51 & .39 & .02 & .21 & .18 & .31 \\
\hline
\end{tabular}

$r \geq[.10], p<.05 ; r \geq[.14], p<.01 ; r \geq[.16], p<.001 ; n=464$

*WFC=Work-to-family conflict; FWC=family-to-work conflict; $\mathrm{MH}=$ mental health; $\mathrm{PH}=$ physical health; $\mathrm{OC}=$ organizational commitment; Loy=loyalty; Inv=involvement; Iden=identification; JD=job demands; JKS=job knowledge and skills; SR=social relationship in the workplace; MLR=management/leadership relations; $\mathrm{RFC}=$ readiness for change.

The first hypotheses (1a-f) were analyzed using a Pearson correlation statistical test with significance determined at the following levels: $r \geq[.10], p<.05 ; r \geq[.14], p<.01 ; r$ $\geq$ [.16], $p<.001$. As predicted, this correlational analysis showed that work-to-family and family-to-work conflict were negatively linked to mental health $(r=-.19 ; r=-.25)$, physical health $(r=-.17 ; r=-.17)$, and organizational commitment $(r=-.30 ; r=-.25)$ and 
its three subscales: loyalty $(r=-.27 ; r=-.17)$, involvement $(r=-.17 ; r=-.31)$, and identification $(r=-.28 ; r=-.19)$, respectively. In addition, this type of conflict was negatively related to social relationship $(r=-.22 ; r=-.23)$, management/leadership relationships $(r=-.28 ; r=-.18)$, and readiness for change scores $(r=-.19 ; r=-.10)$, as predicted. However, no relationship was found between either work-to-family or familyto-work conflict and job knowledge and skills.

The second hypotheses (2a-b) predicted that there would be a positive correlation between work-to-family and family-to-work conflict and job demands, and this was the case. Work-to-family conflict and job demands were strongly related $(r=.48)$ while, although still significant, its relationship with family-to-work conflict was somewhat weaker $(r=.17)$.

\section{Mental and Physical Health Correlates}

The third hypotheses (3a-e) were also analyzed using a Pearson correlation statistical test. As predicted, this correlational analysis showed that mental health and physical health were positively related to organizational commitment $(r=.23 ; r=.21)$ and two of its three subscales: involvement $(r=.30 ; r=.24)$ and identification $(r=.21 ; r=.23)$, respectively. In addition, work-to-family conflict was also related to loyalty $(r=.11)$, however, family-to-work conflict was not. As predict, both (mental and physical health) were also positively related to job knowledge and skills $(r=.37 ; r=.17)$, social relationships in the workplace $(r=.29 ; r=.21)$, management/leadership relationships $(r$ $=.23 ; r=.17)$, and readiness for change scores $(r=.23 ; r=.18)$.

The fourth hypothesis predicted that there would be a negative correlation between mental health and physical health and job demands, and this was the case. Mental health $(r=-.10)$ and physical health $(r=-.16)$ were weakly related to job demands.

\section{Demographic Relationships}

Multiple regressions were used to analyze the relationships between the study constructs and the six demographics variables (i.e., gender, employee age, marital status, education level, number of children, and length of time with employer) and few significant relationships were discovered. In fact, none of the demographics studied appeared to have any predictive power with regard to family-to-work conflict, mental health, or physical health (see Table 3). It does appear, however, that employee age and the length of time an employee worked for a company are weakly (although significantly) related to work-to-family conflict $\left(R^{2}=.029 ; \Delta R^{2}=.15\right)$.

\section{Discussion}

The results of this study suggest that work-family conflict and health are influenced by and/or have influence on many work and nonwork factors. This study provides support for the role conflict theory that states that experiencing ambiguity or conflict within a role will result in an undesirable state. These results suggest that high work-family conflict is related to lower levels of desirable work and nonwork factors (e.g., organizational 
commitment, health); however, we did not study the direction of these relationships. For example, work-family conflict may lead to lower organizational commitment, while health problems and management/leadership concerns may be, at least in part, responsible for increased work-family conflict. In addition, these results also support the spillover theory that states that negative spillover from one role to another is demonstrated when the problems, conflicts, or energy in one role has strained and preoccupied an individual, making it difficult to effectively and positively participate in another, and positive spillover is just the opposite (Foley \& Powell, 1997). For example, good health appears to be related to many constructs including readiness for change, management/leadership relationships, and organizational commitment. This study supports the premise that positive or negative elements from one role (self, work, nonwork) influence or impact elements in another.

Table 3

Demographic Multiple Regressions

\begin{tabular}{|c|c|c|c|c|c|c|c|c|c|c|c|c|}
\hline \multirow{2}{*}{ Variables } & \multicolumn{3}{|c|}{$\begin{array}{l}\text { Work to Family } \\
\text { Conflict }\end{array}$} & \multicolumn{3}{|c|}{$\begin{array}{c}\text { Family to Work } \\
\text { Conflict }\end{array}$} & \multicolumn{3}{|c|}{$\begin{array}{l}\text { Mental } \\
\text { Health }\end{array}$} & \multicolumn{3}{|c|}{$\begin{array}{c}\text { Physical } \\
\text { Health }\end{array}$} \\
\hline & $\mathrm{R}^{2}$ & $\begin{array}{c}\Delta \\
\mathrm{R}^{2}\end{array}$ & $\beta$ & $\mathrm{R}^{2}$ & $\Delta R^{2}$ & $\beta$ & $\mathrm{R}^{2}$ & $\Delta \mathrm{R}^{2}$ & $\beta$ & $\mathrm{R}^{2}$ & $\begin{array}{c}\Delta \\
\mathrm{R}^{2}\end{array}$ & $\beta$ \\
\hline Gender & & & .03 & & & -.08 & & & -.02 & & & -.02 \\
\hline $\begin{array}{l}\text { Employee } \\
\text { age }\end{array}$ & & & $-12^{*}$ & & & -.02 & & & .01 & & & -.11 \\
\hline $\begin{array}{l}\text { Marital } \\
\text { status }\end{array}$ & & & .08 & & & -.05 & & & .05 & & & .04 \\
\hline $\begin{array}{l}\text { Educational } \\
\text { level }\end{array}$ & & & .04 & & & -.01 & & & -.07 & & & .02 \\
\hline $\begin{array}{l}\text { Number of } \\
\text { children }\end{array}$ & & & .04 & & & -.02 & & & .01 & & & .08 \\
\hline $\begin{array}{l}\text { Time with } \\
\text { organizatio } \\
\mathrm{n}\end{array}$ & $\begin{array}{l}.0 \\
3\end{array}$ & .02 & $.14^{*}$ & $\begin{array}{l}.0 \\
1\end{array}$ & -.004 & .03 & $\begin{array}{l}.0 \\
1\end{array}$ & .002 & -.07 & $\begin{array}{l}.0 \\
3\end{array}$ & .02 & -.10 \\
\hline
\end{tabular}

${ }^{*} p<.05 ;{ }^{* *} p<.01$

This research suggests that work-to-family and family-to-work conflict are related to organizational commitment, and this is consistent with much of the past literature (e.g., Good et al., 1996; Tompson \& Werner, 1997). It is possible that employees who are better able to balance the demands of both work and family are able to feel more loyal and involved in their organizations. In fact, these organizations may be assisting employees through work design, flexibility, and other work-family initiatives or programs which may be helping employees better balance their role responsibilities. Employees typically do feel more committed to a company that appears to be committed to and concerned about them. According to Cook and Wall (1980), this commitment stems from employees' loyalty to the company, their perceived involvement in the organization, and the level of organizational identification they feel. Our research found 
that all three contribute to organizational commitment's relationship with both directions of work-family conflict.

Other relationships are also notable. First, the finding that both directions of conflict are linked to job demands makes sense. When employees are feeling high demands for their time and energy at work, the role conflict theory proposes that an employee would then need to make sacrifices in other roles because of this increased strain and stress, thus increasing their work-family conflict. Second, social and management/leadership relationships in the workplace can be examples of an employee's support system. The literature (e.g., Carlson \& Perrewe, 1999) substantiates the premise that supportive environments help reduce an employee's stress and strain. Our findings that lower levels of work-family conflict are related to perceptions of good management/leadership relationships and strong social relationships substantiates past literature (e.g., Anderson et al., 2002; Thomas \& Ganster, 1995). This provides support for the argument that when employees have opportunities to develop healthy and open relationships with management, their work-family conflict levels may decrease. And, as we have already discussed, reduced work-family conflict has been linked to increased productivity and performance (Netemeyer et al., 1996; Eagle et al., 1997). Third, this is one of the first studies that provides support for a relationship between work-family conflict (both directions) and employee readiness for organizational change. It may be that employees have more emotional and physical energy as well as time to make changes if they are not struggling with conflicts between the work and nonwork domains.

This study also suggests the mental health and physical health are related to organizational commitment. In the case of mental health, it appears that all three organizational commitment components are contributors to this relationship (loyalty, involvement, and identification). However, the strongest relationship appears to be with work involvement. An employee's health, both physical and mental, often dictates the level of involvement an employee may have at work. Physical health is also related to organizational commitment, but not because of loyalty. An employee's physical health often determines the level of involvement he or she can have at work. Interestingly, it appears that employees' pride and identification with a company may decrease when he or she does not feel physically well. Overall, according to our results, when employees feel good, they are more loyal, involved, and committed to their organizations. Basically, assisting employees in improving their health may be one method that helps increase overall organizational commitment.

These results also support some existing research. First, findings suggest relationships among work-to-family conflict, family-to-work conflict, physical health, and mental health which are consistent with what others have found (e.g., Kinnumen \& Mauno, 1998; Netemeyer et al., 1996). Second, there was slight evidence that as job demands increase employee's personal health may decrease. However, the opposite may also be the case; if employees feel healthy and energetic they may be able to keep up with job demands and not feel overwhelmed by them. Third, job knowledge and skills appear to be related to both mental and physical health. More specifically, employees who perceive high levels of knowledge and skills related to their jobs also perceive good health. Maybe continued uncertainty and stress related to not knowing what one needs 
to know or not being able to do what needs to be done to perform effectively leads to perceptions of decreased health possibly through increased stress, strain, or depression. Other employees may feel this extra pressure does not let them do the types of activities that would lead them to feel healthy. Future research in this area would be necessary to determine the specific relationship and direction. Fourth, this research also suggests that employees who perceive higher levels of health also have better social relationships in the workplace and better relationships with their managers and leaders. When individuals do not feel well, they may not reach out to create and maintain such relationships. Often, employees with physical and mental struggles have less optimistic attitudes and perceptions toward many issues. Finally, it appears that employees who are healthier are also more open and ready for organizational change. This is a new area of research, and these results are encouraging. In today's business environment, the need for change is constant and continuous. Organizations are trying to find ways to help employees change faster and better. Finding ways to facilitate more readiness for these changes is an emerging area of research. Most likely, the relationship among these constructs is as already stated; as employees become healthier, they are more prepared and ready for organizational and individual change.

\section{Suggestions for Research and Limitations}

There are many areas of research that are imperative for this work to continue moving forward. First, more causal-comparative and experimental research need to be conducted to determine causality of the constructs explored in this study. Relationship directions on some constructs have been purported and proposed but without adequate support. Second, longitudinal studies in this research area are currently rare. Specific research carefully designed to look at changes throughout time can be helpful in understanding these phenomenon as well as possible interventions resulting from these and other related findings. Third, research with regard to work-family conflict and healthrelated workplace antecedents and/or determinants as well as mediators need to continue to be explored and clearly reported. More specifically, additional research designed around the new relationships discovered in this research (e.g., readiness for change, job knowledge and skills) should be investigated. Fourth, specific workplace interventions focused at increasing the constructs addressed in this and other research need to be examined. Pre- and post-surveys should be used to documented changes as they relate to reduced work-family conflict and/or improved health. Finally, there are many possible influential factors for these constructs that have not yet been studied. We would strongly recommend a thorough research project focused on exploration, compilation, and publication of all the management, human resource development, and organizational psychology research on these influential factors specific to the workplace environment should be conducted. Although there are some scholars who have done some of this in work-family conflict, an update is needed. A current and thorough compilation in the mental and physical health and related workplace performance constructs is overdue. Clear identification of these factors and a list of possible or potential factors that have yet to be explored would be most helpful for researchers, scholars, and practitioners. 
Although the sampling methods may have limited the generalizability of these findings, participants were selected from four different organizations and included a variety of individuals with different positions and in different industries. The study was limited to 758 employees; a larger and fully randomized sample would have improved generalizability. In addition, this study was limited only to the factors that may influence change readiness. An individual's work-family conflict and health can be influenced by variables not measured in this study. A questionnaire survey cannot accurately control many variables within an organization's culture or for an individual's situation. Estimates of these constructs were based upon employee perceptions and self-report. Finally, although we used adapted versions of existing instruments the scale reliabilities were good except for the two work-family conflict scales (one being particular poor). Therefore, caution must be used to generalize any of the related results.

\section{Contributions and Implications}

This study offers contributions to management, human resource development, and organizational psychology literature. First, it provides support for some of the existing literature and presents some new constructs for consideration in this area. Second, it provides support for new relationships, such as readiness for change, which may provide support for additional workplace work-family conflict and health interventions. Third, it supports the premise that work-family conflict and health are complex phenomenon and influential factors need to be explored for progress in both research and practice. Finally, although cause-effect conclusions cannot be made from these findings, practitioners may begin to utilize this information to assist them as they assess, design, and evaluate new and existing programs or initiatives.

The results of this study suggest recommendations for practitioners. Many organizational leaders consider health and work-family conflict interventions as nonessential or unrelated to the bottom line. Leaders and managers need to be educated about the relationships among employee productivity/performance (bottom line) and the workplace, psychological, and behavioral correlates that influence them (including health, work-family conflict, organizational commitment, and the others reported in this article). For example, managers and supervisors need to have positive and supportive relationships with their employees. Management training in this and other areas is imperative since most do not understand the positive benefits of having this type of relationship with their employees. Overall, interventions based around these relationships should be considered. This research can also provide support for human resource professionals who are writing proposals for such initiatives.

Organizational leaders who put forth resources (e.g., time, educational opportunities, and money) toward these types of efforts may see the benefits, particularly if connections are made between these constructs and performance/productivity increases. In addition to these increases, if designed and implemented well, these initiatives and interventions can also lead to positive results, excitement, organizational renewal, and increased employee loyalty, commitment, and retention. Importantly, initiatives that have direct or indirect effects on the productivity of our employees can also assist in promoting organizational competitiveness in the market place. 


\section{Appendix A}

\section{Employee Survey}

Part 1: Assume your organization has proposed a change to increase effectiveness and enhance productivity. For this change to be accomplished, it requires your resources and energy. Please determine how likely you are to feel or react in the ways described below. Please answer for yourself. There is no right or wrong answer. Your choice of answer is on a scale from one (1) to seven (7). One equals very unlikely and seven equals very likely.

My willingness or openness to...

\begin{tabular}{llllllll} 
& \multicolumn{1}{c}{$\begin{array}{l}\text { Very } \\
\text { Unlikely }\end{array}$} & & \multicolumn{2}{c}{$\begin{array}{c}\text { Very } \\
\text { Likely }\end{array}$} \\
\hline 1. Work more because of the change is & 1 & 2 & 3 & 4 & 5 & 6 & 7 \\
\hline 2. Solve organization problems is & 1 & 2 & 3 & 4 & 5 & 6 & 7 \\
\hline 3. Be a part of the new project is & 1 & 2 & 3 & 4 & 5 & 6 & 7 \\
\hline 4. Create new ideas is & 1 & 2 & 3 & 4 & 5 & 6 & 7 \\
\hline 5. Find ways to make the change fail is & 1 & 2 & 3 & 4 & 5 & 6 & 7 \\
\hline 6. Do things in a new or creative way is & 1 & 2 & 3 & 4 & 5 & 6 & 7 \\
\hline 7. Change the way I work because of the change is & 1 & 2 & 3 & 4 & 5 & 6 & 7 \\
\hline 8. Take responsibility for the change if it fails in my area is & 1 & 2 & 3 & 4 & 5 & 6 & 7 \\
\hline 9. Be a part of the change program is & 1 & 2 & 3 & 4 & 5 & 6 & 7 \\
\hline 10. Learn new things is & 1 & 2 & 3 & 4 & 5 & 6 & 7 \\
\hline 11. Change something even if it appears to be working & 1 & 2 & 3 & 4 & 5 & 6 & 7 \\
\hline 12. Support change is & 1 & 2 & 3 & 4 & 5 & 6 & 7 \\
\hline 13. Improve what we're currently doing rather than implement a & 1 & 2 & 3 & 4 & 5 & 6 & 7 \\
\hline major change is & 1 & 2 & 3 & 4 & 5 & 6 & 7
\end{tabular}

Part 2: Read each statement and then circle the number that best represents your agreement or disagreement. One (1) equals strongly disagree and seven (7) equals strongly agree.

\begin{tabular}{llllllll} 
& \multicolumn{3}{c}{$\begin{array}{c}\text { Strongly } \\
\text { Disagree }\end{array}$} & \multicolumn{4}{c}{$\begin{array}{c}\text { Strongly } \\
\text { Agree }\end{array}$} \\
\hline 1. I feel an obligation to my job. & 1 & 2 & 3 & 4 & 5 & 6 & 7 \\
\hline 2. My work keeps me from my family activities more than I would like. & 1 & 2 & 3 & 4 & 5 & 6 & 7 \\
\hline 3. I am quite proud to be able to tell people that I work for my company. & 1 & 2 & 3 & 4 & 5 & 6 & 7 \\
\hline 4. The people I have met at my job are great. & 1 & 2 & 3 & 4 & 5 & 6 & 7 \\
\hline 5. Meeting job/task assignment deadlines is very easy. & 1 & 2 & 3 & 4 & 5 & 6 & 7 \\
\hline $\begin{array}{l}\text { 6. The time I spend on family responsibilities often interfere with my work } \\
\text { responsibilities. }\end{array}$ & 1 & 2 & 3 & 4 & 5 & 6 & 7 \\
\hline 7. Working with others is often difficult. & & & & & & \\
\hline 8. My knowledge and skills concerning my present job are strong. & 1 & 2 & 3 & 4 & 5 & 6 & 7 \\
\hline
\end{tabular}




\begin{tabular}{|c|c|c|c|c|c|c|c|}
\hline & \multicolumn{4}{|c|}{$\begin{array}{l}\text { Strongly } \\
\text { Disagree }\end{array}$} & \multicolumn{3}{|c|}{$\begin{array}{r}\text { Strongly } \\
\text { Agree }\end{array}$} \\
\hline 10. Consulting or talking with co-workers is enjoyable. & 1 & 2 & 3 & 4 & 5 & 6 & 7 \\
\hline 11. I feel that I am emotionally stable. & 1 & 2 & 3 & 4 & 5 & 6 & 7 \\
\hline 12. I often work after hours. & 1 & 2 & 3 & 4 & 5 & 6 & 7 \\
\hline 13. I feel that I am an integral part of this company. & 1 & 2 & 3 & 4 & 5 & 6 & 7 \\
\hline 14. My mental health is good. & 1 & 2 & 3 & 4 & 5 & 6 & 7 \\
\hline $\begin{array}{l}\text { 15. I am often so emotionally drained when I finish work that it prevents me } \\
\text { from contributing to my family. }\end{array}$ & 1 & 2 & 3 & 4 & 5 & 6 & 7 \\
\hline 16. It is very difficult to meet my supervisor's expectations. & 1 & 2 & 3 & 4 & 5 & 6 & 7 \\
\hline $\begin{array}{l}\text { 17. I have the knowledge and skills necessary to move up in my } \\
\text { organization. }\end{array}$ & 1 & 2 & 3 & 4 & 5 & 6 & 7 \\
\hline 18. I have freedom from physical pain. & 1 & 2 & 3 & 4 & 5 & 6 & 7 \\
\hline $\begin{array}{l}\text { 19. It would please me to know my work made a beneficial contribution to the } \\
\text { organization. }\end{array}$ & 1 & 2 & 3 & 4 & 5 & 6 & 7 \\
\hline $\begin{array}{l}\text { 20. Tension and anxiety from my family/home often weakens my ability to do } \\
\text { my job. }\end{array}$ & 1 & 2 & 3 & 4 & 5 & 6 & 7 \\
\hline 21. My supervisor is supportive. & 1 & 2 & 3 & 4 & 5 & 6 & 7 \\
\hline 22. I have a demanding schedule at work. & 1 & 2 & 3 & 4 & 5 & 6 & 7 \\
\hline 23. I would not recommend that a close friend join our staff. & 1 & 2 & 3 & 4 & 5 & 6 & 7 \\
\hline 24. My vitality in life is strong. & 1 & 2 & 3 & 4 & 5 & 6 & 7 \\
\hline 25. I have the knowledge and skills required to do my job well. & 1 & 2 & 3 & 4 & 5 & 6 & 7 \\
\hline $\begin{array}{l}\text { 26. In my work I like to feel that I am making substantial effort, not just for } \\
\text { myself, but for the organization as well. }\end{array}$ & 1 & 2 & 3 & 4 & 5 & 6 & 7 \\
\hline 27. My overall health is poor. & 1 & 2 & 3 & 4 & 5 & 6 & 7 \\
\hline $\begin{array}{l}\text { 28. Even if my company were not doing too well financially, I would be } \\
\text { reluctant to change to another employer. }\end{array}$ & 1 & 2 & 3 & 4 & 5 & 6 & 7 \\
\hline 29. Working with my supervisor is a positive experience. & 1 & 2 & 3 & 4 & 5 & 6 & 7 \\
\hline $\begin{array}{l}\text { 30. Behavior that is effective and necessary for me in my job would be } \\
\text { counterproductive in my home/nonwork life. }\end{array}$ & 1 & 2 & 3 & 4 & 5 & 6 & 7 \\
\hline 31. I'm not willing to put myself out just to help the organization. & 1 & 2 & 3 & 4 & 5 & 6 & 7 \\
\hline 32. My relationship to the leaders in my organization is very positive. & 1 & 2 & 3 & 4 & 5 & 6 & 7 \\
\hline 33. I can handle stressful situations effectively. & 1 & 2 & 3 & 4 & 5 & 6 & 7 \\
\hline $\begin{array}{l}\text { 34. The behaviors that work for me in my home/nonwork life do not seem to } \\
\text { be effective for me in performing my work responsibilities. }\end{array}$ & 1 & 2 & 3 & 4 & 5 & 6 & 7 \\
\hline $\begin{array}{l}\text { 35. The offer of a small raise with another company would not seriously } \\
\text { make me think of changing my job. }\end{array}$ & 1 & 2 & 3 & 4 & 5 & 6 & 7 \\
\hline 36. My interpersonal relationships with my co-workers are excellent. & 1 & 2 & 3 & 4 & 5 & 6 & 7 \\
\hline 37. I sometimes feel like leaving this employment for good. & 1 & 2 & 3 & 4 & 5 & 6 & 7 \\
\hline 38. My physical health is excellent. & 1 & 2 & 3 & 4 & 5 & 6 & 7 \\
\hline 39. I am frustrated with the demands of my job. & 1 & 2 & 3 & 4 & 5 & 6 & 7 \\
\hline
\end{tabular}


Part 3: Read each statement carefully and then circle the number (see list below) that best represents your feelings and views. Please read through the five descriptions before answering.

$1=$ Takes a lot of my energy —it physically or mentally drains - a load on my shoulders

2 = Takes some of my energy - it somewhat drains me - somewhat of a load on my shoulders

$3=$ Neither takes energy nor provides job, pleasure, strength, or richness for me. $4=$ Provides or creates some joy, pleasure, strength, or richness for me - gives me some energy/power in my life $5=$ Provides or creates a lot of joy, pleasure, strength, or richness for me - gives me energy/power in my life

\begin{tabular}{llllll}
\hline 1. My job & 1 & 2 & 3 & 4 & 5 \\
\hline 2. Balancing my work and family & 1 & 2 & 3 & 4 & 5 \\
\hline 3. My physical and mental health & 1 & 2 & 3 & 4 & 5 \\
\hline 4. My relationship with my boss & 1 & 2 & 3 & 4 & 5 \\
\hline 5. My social relationships in the workplace & 1 & 2 & 3 & 4 & 5 \\
\hline 6. My current job knowledge and skills & 1 & 2 & 3 & 4 & 5 \\
\hline 7. The demands of my job & 1 & 2 & 3 & 4 & 5 \\
\hline 8. My commitment to this organization & 1 & 2 & 3 & 4 & 5 \\
\hline 9. My family & 1 & 2 & 3 & 4 & 5 \\
\hline
\end{tabular}


Part 4: Please put an $X$ in the appropriate box. Your answers will be confidential; the information in this section will not be reported in a manner that individuals or small groups could be identified. Your company will not see any surveys.

1. Gender:

Male

Female

2. Age Range:

less than 21

21-30

$31-40$

$41-54$

$55+$

3. Present Marital Status:

Single

Separated/Divorced

Widowed

Married

4. Highest Educational Level:

High School

Associate Degree

Bachelor Degree

Masters Degree

Doctorate Degree
5. Number of children (if any) living at home in each age category (write the actual \# of children in the spaces provided):

children Check if you have no

$0-5$ years old 6-11 years old 12-18 years old $19+$ years old

Number not living at home

6. Length of time with company:

$0-6$ months

7-11 months

$1-2$ years

3-5 years

6 or more years 


\section{References}

Anderson, S. E., Coffey, B. S. \& Byerly, R. T. (2002). Formal organizational initiatives and informal workplace practices: Links to work-family conflict and job-related outcomes. Journal of Management, 28(6), 787-810.

Aryee, S., Luk, V., Leung, A., \& Lo, S. (1999). Role stressors, interrole conflict, and wellbeing: The moderating influence of spousal support and coping behaviors among employed parents in Hong Kong. Journal of Vocational Behavior, 54, 259-278.

Batt, R. \& Valcour, P. M. (2003). Human resources practices as predictors of workfamily outcomes and employee turnover. Industrial Relations, 42(2), 189-220.

Biernat, B. A. (1997). Employed parents' preference for reduced job hours in relation to job and family characteristics. Unpublished doctoral dissertation, University of Minnesota.

Burley, K. (1989). Work-family conflict and marital adjustment in dual career couples: A comparison of three time models. Unpublished doctoral dissertation, Claremont Graduate School, Claremont, CA.

Cook J., \& Wall, T. (1980). New work attitude measures of trust, organizational commitment and personal need non-fulfillment. Journal of Occupational Psychology, 53, 39-52.

Carlson, D. S., Kacmar, K. M., \& Williams L. J. (2000). Construction and initial validation of a multidimensional measure of work-family conflict. Journal of Vocational Behavior 56, 249-276.

Carlson, D. S., \& Perrewe, P. L. (1999). The role of social support in the stressor-strain relationship: An examination of work-family conflict. Journal of Management, 25(4), 513527.

Cunningham, C. E., Woodward, C. A., Shannon, H. S., Maclntosh, J., Lendrum, B., Rosenbloom, D. \& Brown, J. (2002). Readiness for organizational change: A longitudinal study of workplace, psychological and behavioural correlates. Journal of Occupational and Organizational Psychology, 75, 377-392.

Daley, A. J., \& Parfit, G. (1996). Good health - It is worth it? Wood states, physical wellbeing, job satisfaction and absenteeism in members and non-members of a British corporate health and fitness club. Journal of Occupational and Organizational Psychology, 69,121-134.

Eagle, B. W., Miles, E. W., \& Icenogle, M. L. (1997). Interrole conflict and the permeability of work and family domains: Are there gender differences? Journal of Vocational Behavior, 50, 168-184. 
Foley, S., \& Powell, G. N. (1997). Reconceptualizing work-family conflict for business/marriage partners: a theoretical model. Journal of Small Business Management, 35(4), 36-47.

Frone, M. R., Russell, M. \& Cooper, M. L. (1997). Relation of work-family conflict to health outcomes: A four-year longitudinal study of employed parents. Journal of Occupational and Organizational Psychology, 70, 325-335.

Frone, M. R. Yardley, J. K., \& Markel, K. S. (1997). Developing and testing an integrative model of the work-family interface. Journal of Vocational Behavior, 50,145167.

Fu, C. K., \& Shaffer, M. A. (2001). The tug of work and family: Direct and indirect domain-specific determinants of work-family conflict. Personnel Review, 30(5), 502-522.

Good, L. K., Page, T. J. \& Young, C. E. (1996). Assessing Hierarchical differences in job-related attitudes and turnover among retail managers. Journal of the Academy of Marketing Science, 24(2), 148-156.

Grandey, A. A., \& Cropanzano, R. (1999). The conservation of resources model applied to work-family conflict and strain. Journal of Vocational Behavior, 54, 350-370.

Greenberg, P. E., Finkelstein, S. N., \& Berndt, E. R. (1995, Summer). Economic consequences of illness in the workplace. Sloan Management Review, 26-38.

Greenhaus, J. H., \& Beutell, N. J. (1985). Sources of conflict between work and family roles. Academy of Management Review, 10(1), 76-88.

Gutek, B., Searle, S., \& Klepa, L. (1991). Rational versus gender role-explanations for work-family conflict. Journal of Applied Psychology, 76(4), 560-568.

Hanpachern, C., Morgan, G. A., \& Griego, O. V. (1998). An extension of the theory of margin: A framework for assessing readiness for change. Human Resource Development Quarterly, 9(4). 339-350.

Hanpachern C. (1997). The extension of the theory of margin: A framework for assessing readiness for change. Unpublished Doctoral Dissertation, Colorado State University, Fort Collins.

Higgins, C. A., Duxbury, L. E., Lee, C., \& Mills, S. (1992). An examination of work-time and work-location flexibility. Optimum, 23(2), 29-37.

Ho, J. T. S. (1997). Corporate wellness programmes in Singapore: Effect on stress, satisfaction and absenteeism. Journal of Managerial Psychology, 12(3), 177-189.

Kinnumen, U. \& Mauno, S. (1998). Antecedents and outcomes of work-family conflict among employed women and men in Finland. Human Relations, 51(2), 157-177. 
Kirchmeyer, C. (1995). Managing the work-nonwork boundary: An assessment of organizational responses. Human Relations, 48(5), 515-536.

Kossek, E. E., \& Ozeki, C. (1999). Bridging the work-family policy and productivity gap: A literature review. Community, Work \& Family, 2(1), 7-32.

Lansing, D. M., \& Kliner, B. H. (1990). How managers can enhance employee health and fitness: Some US case examples. Leadership \& Organization Development, 11(5), i-iii.

Madsen, S. R. (2003a). Wellness in the workplace: Preparing employees for change. Organization Development Journal, 20(5).

Madsen, S. R. (2003b). The effects of telework on work and family conflict. Human Resource Development Quarterly, 14(1), 35-58.

Mathews, B. P. \& Shepherd, J. L. (2002). Dimensionality of Cook and Wall's (1980) British Organizational Commitment scale. Journal of Occupational and Organizational Psychology, 75, 369-375.

McNabb, D. E., \& Sepic, F. T. (1995). Culture, climate, and total quality management: Measuring readiness for change. Public Productivity \& Management Review, 18(4), 369-385.

Netemeyer, R. G., Boles, J. S., \& McMurrian, R. (1996). Development and validation of work-family conflict and family-work conflict scales. Journal of Applied Psychology, 81(4), 400-410.

Rosen, R. H. (1986). Healthy companies: A human resources approach. AMA Management Briefing: Amacom Books.

Stevenson, J. S. (1982). Construction of a scale to measure load, power, and margin in life. Nursing Research, 31(4), 222-225.

Thomas, L. T., \& Ganster, D. C. (1995). Impact of family-supportive work variables on work-family conflict and strain: A control perspective. Journal of Applied Psychology, 80, $6-15$.

Thompson, C. A., Beauvais, L. L., \& Lyness, K. S. (1999). When work-family benefits are not enough: The influence of work-family culture on benefit utilization, organizational attachment, and work-family conflict. Journal of Vocational Behavior, 54, 392-415.

Tompson, H. B., \& Werner, J. M. (1997). The impact of role conflict/facilitation on core and discretionary behaviors: Testing a mediated model. Journal of Management, 23(4), 583-602.

Tracey, J. B., Hinkin, T. R., Tannenbaum, S. \& Mathieu, J. E. (2001). The influence of individual characteristics and the work environment on varying levels of training outcomes. Human Resource Development Quarterly, 12(1), 5-23. 
Voit, S. (2001). Work-site health and fitness programs: Impact on the employee and employer. Work, 16, 273-286.

Yetman, M. (1998). The economic benefits of regular exercise. IHRSA Production Group. 